\title{
O povo do rio: variações míticas e variações antropológicas sobre a origem e a diferenciação dos grupos inỹ ${ }^{1}$
}

River people: mythic and anthropological variations on the
origin and differentiation of the iny groups

Eduardo Soares Nunes²

DOI: http://dx.doi.org/10.20435/tellus.v18i36.489

\begin{abstract}
Resumo: Os Karajá, Javaé e Ixỹbiòwa são três grupos indígenas que habitam a calha do rio Araguaia. Todos falam variantes de uma mesma língua (família Karajá, tronco Macro-Jê) e utilizam o mesmo termo de autodesignação: inỹ. As inúmeras similaridades entre eles tornam evidente que fazem parte de um mesmo conjunto. Por muito tempo, com efeito, os Javaé e Ixỹbiòwa foram tratados como "subgrupos" karajá, ao lado dos "karajá propriamente ditos". A predominância desse modelo hierárquico, entretanto, acabou por eclipsar muitas das diferenças entre os três grupos. Esse texto trata das narrativas karajá sobre a origem e a diferenciação da humanidade inỹ, procurando extrair daí um modelo alternativo para pensar a relação entre os três grupos que fuja tanto de um esquema hierárquico (três "subgrupos karajá"), quanto de uma segmentação dura entre "três grupos distintos"; pois há, entre Karajá, Javaé e Ixỹbiòwa, não apenas diferenciações, como também identificações. O que a mitologia aqui tratada evidencia é que, desde o surgimento mesmo da humanidade, não há mais que uma polaridade elementar, aquela entre Eu e Outro, a emergir no seio de uma unidade aparente e replicando-se a cada novo nível de contraste, ou em cada nova "unidade".
\end{abstract}

Palavras-chave: Inỹ-Karajá; mitologia; dualismo em perpétuo desequilíbrio.

Abstract: The Karajá, Javaé and Ixỹbiòwa are three indigenous groups that inhabit the Araguaia river valley. They all speak variants of a same language (Macro-Jê) and refer to themselves through the same term: inỹ. The countless similarities between them makes it clear that they form a one conjunct. For a long time, indeed, both Javaé and Ixỹbiòwa were classified as Karajá "subgroups", alongside the Karajá proper. The predominance of this hierarchical

${ }^{1}$ Esse texto é, com algumas modificações, um trecho do primeiro capítulo de minha tese de doutorado (NUNES, 2016).

${ }^{2}$ Universidade Federal do Oeste do Pará (Ufopa), Santarém, Pará, Brasil.

Tellus, Campo Grande, MS, ano 18, n. 36, p. 9-38, maio/ago. 2018 
model, however, ended up working to eclipse many of the differences between the three groups. This article deals with Karajá narratives about the origin and differentiation of inỹ humanity, aiming to extract from them an alternative model to think the very relation between the three groups that escapes both from a hierarchical model (three "Karajá subgroups") and from a rigid segmentation between "three distinct groups"; for there are differentiations as well as identifications between the Karajá, Javaé and Ixỹbiòwa. The mythology fragments here presented evinces that, from the very beginning of humanity, there is nothing but an elementary polarity - that between Self and Other emerging in the midst of an apparent unity and replicating itself at every new level of contrast, or, there is to say, at each new "unity".

Keywords: Inỹ-Karajá; mythology; dualism in perpetual disequilibrium.

\section{INTRODUÇÃO}

Os Karajá, Javaé e Ixỹbiòwa são três grupos indígenas que habitam a calha do rio Araguaia. Todos falam variantes do inỹrybè - língua da família Karajá, tronco Macro-Jê (DAVIS, 1968) - e utilizam o mesmo termo de autodesignação: inỹ, "nós", "gente". As inúmeras similaridades nos usos e costumes, alimentação, ritual, ornamentação, cosmologia, morfologia de aldeia etc. tornam evidente que os três grupos fazem parte de um mesmo conjunto. Por muito tempo, com efeito, os Javaé e Ixỹbiòwa foram tratados como "subgrupos" karajá, ao lado dos "karajá propriamente ditos".

A predominância desse modelo hierárquico, entretanto, fez com que as diferenças entre os três grupos permanecessem em boa parte eclipsadas durante décadas. Os trabalhos de Patrícia Rodrigues sobre os Javaé (1993; 2008a) - a primeira etnografia dedicada ao grupo - tornaram isso mais que evidente. $\mathrm{E}$ também entre os próprios Karajá há várias diferenças que não são menores. Há, para começar, uma diferenciação entre os agrupamentos de aldeias meridionais, os ibòò mahãdu ổ (Karajá "de cima"), e setentrionais, os iraru mahãdu (Karajá "de baixo"), diferenciação essa que apresenta correlatos linguísticos e socioculturais. E essa oposição ibòò ô x iraru ("de cima" x "de baixo") se replicada dentro de

\footnotetext{
${ }^{3} \mathrm{O}$ inỹrybè, a língua falada pelos três povos que se autodesignam como Inỹ, os Karajá, Javaé e Ixỹbiòwa, apresenta uma diferenciação da fala pelo sexo do falante (ver RIBEIRO, 2012). As variantes feminina e masculina das palavras aparecem indicadas no texto por meio dos símbolos q e $\hat{o}$, respectivamente.
} 
cada aldeia na forma de grupos cerimoniais cuja pertença remete, em grande parte, à origem territorial.

Esse texto trata das narrativas dos Karajá de Santa Isabel do Morro sobre a origem da humanidade inỹ e a diferenciação entre seus três grupos, concomitante com seu estabelecimento em diferentes trechos do rio. Mais que um simples registro dessas narrativas - e de algumas de suas variantes -, procuro extrair daí um modelo alternativo para pensar a relação entre os três grupos que fuja tanto de um esquema hierárquico (três "subgrupos karajá", o que implica uma relação entre um todo e suas partes), quanto de uma segmentação dura entre "três grupos distintos"; pois há, entre Karajá, Javaé e Ixỹbiòwa, não apenas diferenciações, como também identificações. Desde o surgimento mesmo da humanidade, veremos, não há mais que uma polaridade elementar, aquela entre Eu e Outro, semelhante e diferente - que aparecerá ora como entre inỹ e ixỹju ("povos estrangeiros"), ora como entre ibòò e iraru ("de cima" e "de baixo", montante e jusante) - a emergir no seio de uma unidade aparente e replicando-se a cada novo nível de contraste, ou em cada nova "unidade".

\section{FIM DOS PRIMEIROS HUMANOS}

Os grupos inỹ ocupam imemorialmente a calha do rio Araguaia. Suas aldeias, sempre à beira do rio, de um lago ou curso d'água menor, se espalham ao longo de mais de mil quilômetros às margens desse caudaloso rio que corta o Brasil central, margeando os territórios dos estados de Goiás, Mato Grosso, Tocantins e Pará. Os primeiros registros de viajantes relatam já a presença desses indígenas nos barrancos altos e, principalmente, nas praias do Araguaia. E tampouco há registros na história oral de que tenham migrado de outra região. A partir disso, Nathalie Pétesch afirma que a ocupação inỹ nessa região seria anterior à invasão europeia ao continente sul-americano. E se pergunta:

De quando remonta, então, o estabelecimento desse grupo indígena ao vale do Araguaia? A arqueologia da bacia do Araguaia não está mais do que em seus princípios. As primeiras pesquisas feitas no alto Araguaia, notadamente no rio Vermelho e na região de Aruanã, foram, porém, capazes de estabelecer numerosas analogias entre a cerâmica tradicional karajá e os vestígios encontrados nos sítios [arqueológicos] dos primeiros horticultores e ceramistas do sul do estado de Goiás e do Mato Grosso (tradição Uru, século IX). 
Isso parece indicar que a origem dos Karajá, ou de seus ancestrais, é muito antiga nesta região. (PÉTESCH, 1992, p. 34, tradução minha).

A limitação dos registros historiográficos e arqueológicos, porém, contrasta com a riqueza das narrativas inỹ, que elaboram em minúcias o tema do surgimento da humanidade e da ocupação da calha do Araguaia. As etnografias karajá apontam para uma única narrativa como o "mito de origem da humanidade", aquela que conta como os Inỹ que habitavam o Berahatxi, o mundo subaquático, patamar inferior do cosmos, descobriram uma passagem para o mundo de fora e saíram para viver às margens do Araguaia. Essa é talvez a narrativa karajá mais conhecida e publicada ${ }^{4}$, utilizada inclusive por Lévi-Strauss (2004) em sua análise dos mitos da vida breve.

A única referência que encontrei na literatura específica sobre um possível deslocamento do grupo a partir de outra região é um trecho de uma fala do finado Arutỹna, de Santa Isabel, registrada por Edna de Melo Taveira (2012, p. 23-4):

Antigamente Karajá veio do mato. A nação veio do mato. Veio encontrar o Araguaia e ficou aí morando. Depois fez festa, festona mesmo. E tiraram o menino maior para pôr no meio do grande. Aí conta o caso da Casa de Aruanã. Negócio do Aruanã.

Arutỹna segue contando um resumo da história do fim da primeira humanidade, que veremos adiante. Mas este é um relato isolado. As histórias sobre o começo de tudo já nos mostram os Inỹ morando às margens do Araguaia. Suas aldeias, porém, ficavam no interior da Ilha do Bananal e junto ao rio Javaés, braço menor do Araguaia que forma a Ilha - isso, muito antes de aqueles que moravam no fundo do rio, saírem para o lado de fora.

Certa feita, eu conversava com Mahuèdèru ${ }^{5}$ sobre as histórias dos primeiros tempos. Eu perguntava a ela se, quando os Inỹ saíram do fundo do rio, Ànỹxiwè (o grande demiurgo da mitologia inỹ) ainda vagava sobre a terra. Ela me respondeu que a história da saída do fundo do rio wijina-le ihỹmỹhỹre!, "é recente!", e que as narrativas que contam sobre os primeiros humanos são hitxina hitxina ijàky,

\footnotetext{
${ }^{4}$ Ver Pétesch (1992, p. 445), Erenheich (1948, p. 79-80), Donahue (1982, p. 36-7 e p. 161-2), Rodrigues (2008a, p. 82-7; 2008b, p. 77), Pimentel da Silva e Rocha (2006, p. 102-80), Lipkind (1940, p. 248-9) e Taveira (2012, p. 23-7), para citar apenas alguns dos principais trabalhos sobre o grupo.

${ }^{5}$ Mahuèdèru foi minha principal narradora. As histórias aqui apresentadas me foram narradas por ela e por Dòrèwaru, sua prima. Por uma questão de economia textual, não apresento aqui a íntegra das traduções de suas narrativas, que se encontram em anexo à minha tese (NUNES, 2016).
} 
"histórias muito, muito antigas!". Essa humanidade primeva foi extinta, em um episódio trágico. Só dois irmãos sobreviveram. E é em substituição (tèròwy-mỹ) a estes que os berahatxi làdu, os "habitantes o fundo do rio", vêm para o mundo de fora. Vejamos os seguintes trechos de gravações com Mahuèdèru e Dòrèwaru.

\section{Mahuèdèru}

Eu vou contar, hoje eu vou contar uma história sobre os tempos antigos, eu vou contar. [...]

Não é sobre a saída dos Inỹ do fundo do rio. Antigamente existia Inỹ no mundo de cá, do lado de fora; antigamente, não nos tempos de hoje, há muito tempo. Existiam Inỹ no mundo de cá, tinham pessoas, os Inỹ já existiam. Há histórias sobre o pessoal que morava do lado de cá, existia Inỹ desse lado mesmo.

\section{Dòrèwaru}

Antigamente existiam aldeias inỹ do lado de lá, do lado do rio Javaés. Foi lá que os pirarucus acabaram com uma turma de homens ${ }^{6}$, foi lá mesmo. Foi lá que as mulheres namoraram com o jacaré, foi lá mesmo. Foi lá que, como se diz... Ah sim! Tinha um pote muito grande, no tempo em que a água secou, foi lá que aconteceu, foi lá. Lá mesmo. Antigamente a água era bem limpa. Então os hàri [xamãs] a roubaram, roubaram e colocaram o pote em um lugar aberto. Com isso a água secou. Kubele quebrou o pote. Estava ali, em um lugar limpo. Os hàri fizeram assim, eles roubaram, ficava em um lugar limpo. Foi lá mesmo que aconteceu a história de inỹ wèbòhòna. Foi do lado de lá, antigamente, que as coisas começaram.

Então esse pessoal acabou. Talvez o pessoal que saiu do lado de cá veio para substituí-los, saíram do fundo do rio para ficar no lugar daquele pessoal que acabou. Assim nossos avós contavam.

\section{Mahuèdèru}

Então nosso avô, aquele que era pai de bebê, veio para o lado de cá e descobriu um lugar. Por causa dele as pessoas dizem: "eu sei como as coisas começaram, tudo começou lá em baixo ${ }^{7 \prime}$. Como assim tudo começou lá em baixo? Não foi lá em baixo que os Inỹ apareceram pela primeira vez!

\footnotetext{
${ }^{6} \mathrm{~A}$ narradora lista algumas histórias que aconteceram nesse tempo e que foram protagonizadas por essa humanidade primeva. Para nosso propósito aqui, é de especial interesse a história de inỹ wèbòhòna, que narra como essa primeira humanidade acabou, abrindo caminho para os que saíram do fundo do rio. Nos deteremos sobre ela adiante.

${ }^{7}$ A narradora, que é de Santa Isabel, diz "lá em baixo" se referindo ao local de ascensão dos Inỹ que viviam no fundo do rio, local esse conhecido como inỹsèdyna e que fica pouco acima da aldeia Macaúba, distante de Santa Isabel aproximadamente $125 \mathrm{~km}$ rio abaixo.
} 
Há muitas histórias sobre esses primeiros humanos. Eles viveram muito tempo na Ilha do Bananal e se envolveram em uma série de episódios que culminaram na conformação do mundo tal como existe hoje (como o roubo do sol pelo demiurgo Kànỹxiwè + , Ànỹxiwè $\widehat{~}$ ), na aquisição pelos Inỹ de bens culturais como o fogo, e na origem de diversas coisas, como os vários tipos de gentes e seus corpos particulares, comportamentos habituais/convencionais, técnicas etc. (desde o comportamento das onças em relação aos Inỹ ou a pesca do pirarucu até a origem dos animais e dos brancos) (ver NUNES, 2016, anexo, M01 a M11).

Mas esses primeiros humanos foram extintos de maneira trágica (ver NUNES, 2016, p. 546-53, M11). Tudo aconteceu por conta da revelação de um segredo. Era época do Hetohokỹ, o grande ritual coletivo de iniciação masculina. Naquele tempo, quando os homens saíam para caçar/pescar para trazer comida para os jyrè (os iniciandos), os meninos eram levados para a casa de suas mães e voltavam para a reclusão na casa ritual, quando os homens retornavam (hoje, os jyrè são levados para o mato junto com os homens). Havia dois irmãos sendo iniciados, Ura-Ura, e Yriwàna $\hat{\delta}$, Kyriwàna $q$, que era mais novo. Sempre que os homens iam caçar, a mãe deles perguntava para Ura-Ura como os wakuràsỹ ${ }^{8}+$ comiam na casa dos homens. Ele nunca respondia. Até que um dia, o menino se cansou da insistência da mãe e lhe contou. Disse que os woràsỹ ô encavalavam um dedo sobre o outro, do mindinho ao indicador, para comer. A mulher se animou com a descoberta.

Mas, no canto da casa, estava um velho chamado ljakabukabu. Ele ficava sempre deitado à beira do fogo, coberto de cinzas; como um doente, ele não se levantava e não caminhava mais. Ele estava deitado lá e escutou o que o menino disse. E, apesar de o que ele contou não ter sido nada de muito importante, ele violou uma regra ritual, revelando para uma mulher parte do "segredo masculino", um conhecimento que cabe exclusivamente aos homens. ljakabukabu se levantou e, usando uma vara comprida como apoio, foi até o porto esperar a chegada dos woràsỹ. Quando estes estavam chegando, viram o velho e estranharam: algo estava errado. Encostaram no barranco, subiram e perguntaram ao velho o que

\footnotetext{
${ }^{8} \mathrm{O}$ coletivo anônimo dos mortos, espíritos nos quais os homens se transformam em vários momentos do ritual de iniciação (ver NUNES, 2016, capítulo 5).
} 
estava acontecendo, e ele contou. Na mesma hora o Hãrabòbò ${ }^{9}$ veio correndo e cortou a cabeça do velho ljakabukabu, espetou-a na vara comprida na qual ele se apoiava para andar e foi correndo pela aldeia. Passou por todas as casas, depois foi para o ijoina - o pátio ritual -, onde jogou a cabeça fora.

As mulheres e crianças correram para dentro de casa com medo; já os homens, nenhum foi para casa ficar com sua família, foram todos para o ijoina. Lá eles conversaram e decidiram que todos iriam morrer. Dois homens, Uberia e Hoijàma, comandavam tudo. Eles mandaram um grupo buscar casca de landi para lenha e outro cavar dois grandes buracos, um para queimar as crianças e outro para queimar os adultos. Atearam fogo nos buracos e, quando estavam só brasa, os homens começaram a buscar seus parentes e jogá-los no buraco; depois jogaram-se uns aos outros. Quando as pessoas caíam no fogo, seus olhos derretiam, e sua barriga estourava, kàtòk! Por isso o lugar - e, consequentemente, a história - ficou conhecido como ixỹ wèbòhòna, "o que serve para estourar a barriga das pessoas".

Ninguém escapou. Aqueles que tentaram fugir também morreram, pois os animais ficaram muito bravos. Os que fugiam pelo rio, as piranhas atacavam e matavam; os que fugiam pelo mato, algum animal atacava e matava. Até que sobraram só os dois que comandavam tudo. Eles cantaram, cantaram, cantaram, até próximo do raiar do dia. Assim eles cantavam: "Huberia Hoijàma koni, Huberia Hoijàma koni..."10. Então um deles falou: "Wahy [meu amigo], como vai ser?" E o outro respondeu. "Vai ser assim. Todo mundo, nossas irmãs, todos acabaram. Nós acabamos com nossas irmãs, com nossos sobrinhos. Não vai ser com borduna, vamos furar o fígado um do outro com juasa"11. Eles estavam cantando na beira

\footnotetext{
${ }^{9}$ Um aõni, um tipo de "espírito".

${ }^{10}$ Uberia $\widehat{\jmath}$, Kuberia $q$ e Hoijàma $\widehat{\partial}$, Koijàma $q$ são os nomes dos dois. A última palavra do verso, entretanto, não me é clara. A narradora parece pronunciar como "koni". Junto com Kahukaxi, que me ajudou na revisão de uma outra gravação, na qual essa música também é cantada, chegamos a conclusão de que a palavra seria "kuni", um dos tipos de espectro dos mortos, de modo que a tradução da letra seria algo como: "Espírito de Uberia e Hoijàma!". Revisando a presente narrativa com Xirihore, entretanto, ele me disse que essa última palavra seria "kohi" e que não teria significado algum, seria apenas um som para conferir melodia à música - assim como o nome de Uberia é pronunciado como "Huberia". Mantive a palavra como "koni", da maneira como a narradora parece pronunciar, o que também não tem significado, servindo apenas para fins melódicos. ${ }^{11}$ Um tipo de flecha cuja ponta é feita com uma espécie venenosa de taquara.
} 
do buraco. Então empurraram seus juasa um contra o fígado do outro e caíram para morrer junto com os seus.

Quanto àquele culpado de tudo ${ }^{12}$, sua mãe havia cavado um buraco dentro de casa, escondido ele e seu irmão dentro e coberto com uma grande panela. De lá eles escutaram tudo, o desespero das mulheres e os dois homens cantando. Quando a música parou, quando tudo ficou quieto, eles saíram. Andaram pela aldeia para ver se alguém tinha sobrevivido, mas não sobrou ninguém. Então eles foram pescar. Na ponta da travessa de sua casa havia dois periquitos, criação (nõhõ) dos sobrinhos uterinos de Ura-Ura e Yriwàna. Quando os dois saíram, os periquitos conversaram: "Minha irmã mais nova, vamos fazer calugi para ajudar nossos tios." "Está bem". Então se transformaram em gente e começaram a pilar milho. Pilaram, pilaram, depois prepararam a bebida. Quando estava pronto, se transformaram novamente em periquito e voltaram a sentar na travessa da casa.

Os dois voltaram, encontraram o calugi pronto e concluíram que alguém tinha sobrevivido. Depois que tomaram a bebida, saíram de novo. Mas apenas desceram para suas canoas e se esconderam, até que escutaram o barulho do pilão. Subiram silenciosamente, entraram um por cada porta da casa e surpreenderam as duas moças (ijadòòma) fazendo calugi. Eles perguntaram para elas, insistiram, até que as duas revelaram que eram os periquitos, nõhõ de seus sobrinhos uterinos. Os dois irmãos se casaram com as duas mulheres-periquito e tiveram muitos filhos. Depois os filhos de um casaram com os filhos do outro, e assim eles aumentaram novamente. Por isso hoje existem os biri riokorè $\hat{\sigma}$, biri ritxokorè $q$, os "netos de periquito"; sua pele é clara e suas testas são compridas.

Eles ainda viveram ali por um tempo. Dizem que essa aldeia ficava no rio Wabe (Riozinho), que corta o centro da Ilha do Bananal. Depois Ura-Ura e Yriwàna, junto com suas mulheres-periquito e seus filhos, vieram para o lado do Araguaia. Chegando aqui, eles encontraram uma multiplicidade de pessoas e povos que tinham saído do fundo do rio.

12 Tàki ràki bàdè kòraru-ki, diz a narradora, "ele, o que está no começo/o que provocou/o responsável/o culpado". 


\section{A SAÍDA DO FUNDO DO RIO E A EXPULSÃO DOS WÈRÈ}

O Berahatxi, o "fundo do rio", é um mundo subaquático, patamar inferior do cosmos. Lá vivia um grupo inỹ. Uma história conta como eles saíram para o lado de fora (ver NUNES, 2016, p. 553-6, M12). Woubèdu $\hat{\sigma}$, Wokubèdu + , tinha tido filho recentemente e estava de resguardo. Primeiro ele vomitou, depois saiu para procurar mel. Assim os pais de recém-nascido (tohoũa $q$ tàby) faziam, antigamente. Ele foi andando, entrou em um trilheiro bem estreito, foi indo, foi indo, até que saiu para o lado de cá. Andou pelas praias do rio, depois entrou no mato. Além do mel, que havia em quantidade, ele juntou muitas frutas maduras, èrỹdèsi, èrỹsò, hãtàmõ, õriàlà, samõ. Ele voltou por cima de seu rastro, levando as frutas para seu pessoal experimentar. Woubèdu contou sobre o lugar que havia descoberto e entregou as frutas para seus filhos provarem. Eles decidiram, então, vir morar aqui. Todos vieram, mulheres, homens, todos vieram com suas famílias ${ }^{13}$.

Os que saíram ficaram vivendo juntos, sob o comando de Woubèdu. Entre eles, havia também os ixỹju, muitos índios diferentes. Todos os outros índios saíram junto com ele, junto com o pai de bebê, todos saíram com seus filhos: Wou $\widehat{o}$, Woku + (Tapirapé); Wèrè; Wèrèraòra; Wèrètyhy; Werehina; Werekina; Wyry; Yrysa $\widehat{0}$, Kyrysa $q$ (Xavante, Xerente); Àralahu $\widehat{O}$, Kralahu $q$ (Kayapó); Kymỹkò; Hãrakuè

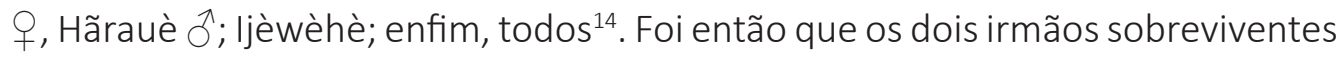
de inỹ wèbòhòna chegaram com suas famílias ao Araguaia. Ura-Ura perguntou para Woubèdu quem eram aqueles, e ele explicou que eram ixỹju. Ura-Ura perguntou de um por um, e Woubèdu foi dando seus nomes e falando sobre eles.

Assim todos viveram juntos e pacificamente por um tempo, sob o comando de Woubèdu, o inỹdèri, o "verdadeiramente humano", "verdadeiramente pessoa". Mas essa paz não poderia durar muito, pois, como disse Mahuèdèru, taràki

\footnotetext{
${ }^{13}$ Nesse momento aparece uma outra personagem: Kàboi também se prepara para sair, mas fica entalado no buraco devido a sua enorme barriga. Apenas com a cabeça para fora, ele vê árvores mortes e assevera que ali não é um bom lugar para viver, pois, ao contrário do mundo subaquático, há morte. Ele retorna com os seus para o Fundo do Rio e, em algumas versões, sela a passagem. Esse é certamente o trecho mais célebre dessa história; inclusive para os Inỹ que, por vezes, se referem a ela como Kàboi-mỹ ijyy $\widehat{0}$, "a história de Kàboi".

${ }^{14}$ Essa lista de nomes dos outros povos que saíram do fundo do rio junto com Woubèdu foi composta a partir das versões de Mahuèdèru, Dòrèwaru (ambas de Santa Isabel) e Abitxỹna (de Fontoura). Mas todos são enfáticos em dizer que todos os índios que existem hoje, assim como outros que se extinguiram, saíram do Berahatxi junto com os Inỹ.
} 
hè anõbina kàdeakakre ixỹju-mỹ rexikòry-mỹ hãdèburè-mỹ, "uma guerra podia acontecer, porque os ixỹju são bravos e iriam procurar briga". Parecia inevitável. E aconteceu quando os Kymỹkò derrubaram/jogaram o tòò de Woubèdu. Tòò é o nome do mastro erguido no pátio ritual e que é alvo de uma disputa entre os anfitriões e visitantes no ápice do Hetohokỹ, a festa de iniciação masculina: os visitantes puxam o mastro com um cipó, tentando derrubá-lo, e os anfitriões, também com um cipó, fazem força no sentido contrário, tentando mantê-lo em pé. Mas a festa de iniciação dos meninos acabou junto com o pessoal de Ura-Ura em inỹ wèbòhòna e só seria recuperada tempos depois ${ }^{15}$. A palavra, com efeito, se refere a qualquer mastro alto, como os esteios centrais das casas, por exemplo. Não se sabe qual tòò era esse que os Kymỹkò derrubaram. Só se sabe isso, e a história tem sido contada de avós para netos assim, dizendo apenas que Kymỹkò ixỹju inỹ labikè ràki Wokubèdu tòò-di ràki rehure, "os ixỹju Kymỹkò derrubaram/ jogaram o tòò de nosso avô Woubèdu".

Em decorrência disso, teve início uma série de conflitos. Aqueles que antes viviam juntos e pacificamente, começaram a brigar uns com os outros. Esse estado de guerra parece ter durado muito tempo, e os ixỹju foram se espalhando, cada um procurando um lugar para si. Alguns povos sumiram, tendo muito provavelmente sido extintos. Os Inỹ não sabem o que aconteceu com vários deles. É o caso dos ljèwèhè. Há um local ao lado de São Félix do Araguaia, MT, cujo nome é ljèwèhè tòla, "furo dos Ijèwèhè", em uma região que era de ocupação Wèrè. Mas não se sabe o que aconteceu com eles, se simplesmente foram embora ou se foram mortos pelos Wèrè ${ }^{16}$.

\footnotetext{
${ }^{15}$ Há uma outra narrativa que conta como uma mulher desrespeita o resguardo, acaba indo morar com um grupo ixỹju, e volta para os seus com filhos em idade de iniciação; a festa, então, é feita para eles (ver NUNES, 2016, p. 564-6, M16).

${ }^{16} \mathrm{Na}$ tese de Patrícia Rodrigues, sobre os Javaé, encontramos uma passagem sobre o assunto: "De acordo com a primeira versão, quando os Wèrè chegaram em Hãwalò Dèsè, no Araguaia, tornaram-se vizinhos dos Ijèwèhè, que moravam onde hoje está São Félix do Araguaia. Um pequeno fragmento mítico narra como os Wèrè, que começaram a pescar demais e a acabar com os peixes locais, envolveram-se em conflitos com os ljèwèhè, que ficaram furiosos com a diminuição do peixe, a ponto de matar um dos Wèrè.

Em sua busca por vingança, os Wèrè cercaram a aldeia dos ljèwèhè, que estava vazia, e queimaram as casas. Quando voltaram ao local, no dia seguinte, encontraram a aldeia toda reconstruída. Novas tentativas foram feitas, mas os ljèwèhè tinham poderes mágicos e sempre escapavam, transformando-se em outros seres ou desaparecendo simplesmente. O lugar onde os ljèwèhè sumiram definitivamente - eles foram para o Biu (Céu) - existe até hoje, e é chamado ljèwèhè
} 
Os Inỹ ficaram morando no lugar onde hoje está a aldeia Itxala, precisamente no encontro entre os rios Tapirapé e Araguaia, próximo ao inỹsèdyna, a passagem por onde todos saíram do fundo do rio. Os Wèrè são lembrados como muito belicosos, dizem que atacavam a todos que encontravam. Eles subiram o rio e dominaram o Araguaia até a região onde hoje está a cidade de São Félix do Araguaia e a aldeia de Santa Isabel do Morro (Hãwalò). E, de tempos em tempos, eles atacavam os Inỹ. Em uma dessas investidas, o pai de Teribrè foi morto. Ele ainda era menino. Uma outra narrativa conta como ele e seu irmão mais novo se prepararam durante muito tempo para vingar a morte do pai, expulsando os Wèrè do Araguaia e estabelecendo o domínio inỹ sobre a calha desse rio (ver NUNES, 2016, p. 571-8, M19).

O pai de Teribrè foi morto pelos Wèrè no mato, e ele cresceu sem pai. Ainda pequeno, vivia brincando com seu irmão. Um dia eles estavam procurando alguma coisa para comer, em casa, e sua mãe ficou brava: "Comida, comida, comida! Vocês só pensam em comer! Vocês não estão se lembrando da morte de seu pai, vocês não estão lembrando que seu pai está morto!". Teribrè ficou bravo, e então falou para seu irmão mais novo, Wanahua, um bàdèòbyna $\widehat{\sigma}$, um "filho adotivo", um Kayapó criado entre os Inỹ: "meu irmão mais novo, vamos tomar banho". Os dois atravessaram para a praia e ficaram dentro d'água direto. Eles fincaram uma vara em um local de correnteza mais forte, se seguraram nela e soltaram os pés, deixando o corpo flutuar na água. Saíram bem cedo, sem comer nada, e ficaram dentro da água direto. Com o sol a pino, eles sentiram frio. Então saíram e esquentaram o corpo ao sol. Depois voltaram para a água e ficaram até o fim da tarde. Quando estava quase escurecendo, os dois voltaram para a aldeia. Todos os dias eles faziam do mesmo jeito: atravessavam cedo, de jejum, se esquentavam ao sol quando sentiam frio e depois voltavam para a água até o final da tarde.

Eles fizeram assim todos os dias, por muito tempo, e na água mesmo eles foram crescendo, se tornaram rapazes (weryrybò) bem grandes. Seus cabelos também cresceram, a água fez seus cabelos ficarem bem compridos. Então sua mãe começou a preparar seus enfeites, dexi, woudexi, wulairi, nõhõsa, todos seus enfeites. E eles continuavam tomando banho no rio. Então o boto (buhỹ),

Kõnana. Os ljèwèhè, povo invencível e poderoso, também são um dos únicos que os temidos Wèrè não exterminaram ou escravizaram, assim como os Tapirapé" (RODRIGUES, 2008b, p. 82). 
o peixe cuiu-cuiu (èhy), todos os animais da água, o peixe filhote (bèdò), todos começaram a passar por baixo deles, roçando no corpo dos dois, e assim eles deixavam seu àlàtà ${ }^{17}$ neles. O corpo dos dois, então, se acostumou com a água, até que eles deixaram de sentir frio: ficavam tomando banho o dia todo, sem precisar se aquecer. Sua pele ficou dura. Então Teribrè e Wanahua fizerem dois arcos pequenos, com uma flecha para cada um: eles queriam se testar. Wanahua atirou a flechinha no peito do pé de Teribrè, que sentiu um pouco de dor, e disse para seu irmão: "Está doendo. Então eu não vou te flechar, não, porque doeu no meu pé. Vamos tomar banho de novo".

E eles continuaram atravessando para praia, todos os dias, tomando banho direto, sempre dentro da água. Eles ficaram com a pele bem escura. Depois de mais um tempo tomando banho, resolveram se testar novamente. Wanahua atirou a flechinha no peito do pé de Teribrè; a flecha bateu e pulou, não entrou na pele dele e ele não sentiu nada. Então Teribrè atirou sua flechinha no peito do pé de Wanahua, que também não sentiu nada. Eles ficaram ityhy, fortes, valentes. No dia seguinte, foram tomar banho pela última vez. Depois ficaram na aldeia, sempre dentro de casa, por um bom tempo ainda. Sua mãe terminou os enfeites deles, fez seus deobutè e também seus raòtuè. Ficaram muito tempo dentro de casa, até que sua pele ficou bem clara. Eles se tornaram dois rapazes muito bonitos, todos enfeitados.

Teribrè, então, chamou Wanahua para fazer flechas. Eles fizeram muitas e muitas. Depois fizeram um cesto bèhyra e o encheram de flechas. Quando estava pronto, falaram para sua mãe que iriam atrás dos Wèrè, buscar a vingança pela morte de seu pai. E foram. Foram subindo o rio, foram, foram... até que avistaram a aldeia dos Wèrè. Quando se aproximaram, um homem veio até eles e perguntou quem eram. Teribrè respondeu dizendo seu nome. Um outro, então, correu para avisar o chefe deles, que ordenou: "Matem-no!" Os Wèrè atiraram suas flechas contra eles, e eles revidaram. Mas Teribrè e Wanahua tinham ficado com a pele dura, grossa, as flechas não entravam, batiam neles e pulavam: os dois irmãos estavam sendo atingidos, mas nem sequer sentiam. Já os Wèrè, estavam mor-

\footnotetext{
${ }_{17}^{17}$ Àlàtà é um visco corporal, característico de certos animais e aõni. Peixes de couro e alguns de escama, como a piranha e a curvina, por exemplo, têm àlàtà, um visco ou "baba" que torna sua pele escorregadia.
} 
rendo. Quando restavam apenas uns três ou quatro, o chefe deles mandou os rahetodu mahãdu (rapazes, weryrybò) para combater os dois irmãos. Eles foram e morreram todos. Então o chefe mandou os bòdu; mas também foi em vão. Por último, ele mandou os jyrè ${ }^{18}$, que também morreram.

Teribrè e Wanahua iam entrar na aldeia para matar o resto dos Wèrè, velhos, mulheres e crianças. Tentando evitar isso, o chefe foi até eles levando uma mulher separada, wàtèsè. "Teribrè, eu trago ela para você". Mas ele recusou. O chefe correu e buscou uma moça, ijadòòma, diz que era muito bonita. Ofereceu-a para Teribrè, e ele também recusou. Ele trazia mulheres e oferecia para que Teribrè se casasse com elas, mas Teribrè recusava. Então o chefe correu e trouxe uma menina, uma hirarihikỹ ${ }^{19}$. Com raiva, Teribrè aceitou. Ele, porém, não a levou para se casar com ela, mas sim como sua wetxu ("serva"), para ficar trabalhando para ele. Teribrè voltou trazendo a menina; os parentes dela, entretanto, seus avôs e avós, tios e tias, pai e mãe, vieram atrás dele e ficaram morando junto com Teribrè. Lá eles trabalhavam muito: um ia buscar lenha, outro ia pescar, uma ia pilar para fazer calugi, outra ia ralar mandioca. Depois preparavam a comida. Quando estava pronto, eles ofereciam primeiro para Teribrè, que recusava: "Comam vocês essa comida, podem comer". Ele era inarèrèhèdu, estava acostumado a fazer jejum, não sentia fome ${ }^{20}$. Os Wèrè não queriam que a menina trabalhasse, então eles mesmos trabalhavam para Teribrè, em lugar dela. Por isso eles foram junto.

O tempo foi passando e. lá mesmo, na aldeia dos Inỹ, a menina menstruou, se tornou ijadòòma. Até que Teribrè começou a ficar desgostoso com tantas pessoas estranhas em sua casa. Mas também sentiu dó deles. Então ele chamou o pai da moça e Ihe disse que poderia voltar com sua filha: "Eu vou entregar

\footnotetext{
${ }^{18}$ Jyrè, bòdu e wekyrybò + , weryrybò ổ são as três categorias de idade pós-iniciação, dos recém-iniciados aos rapazes em idade casável. Os weryrybò são também chamados de rahetodu mahãdu ("os que usam raheto"), pois o uso do maior e mais belo adorno plumário de cabeça (raheto) é prerrogativa de sua faixa de idade.

${ }^{19}$ Hirarihikỹ são meninas de sete anos, aproximadamente, até a primeira menstruação, quando tornam-se ijadòòma $\widehat{\partial}$, ijadòkòma $q$.

${ }^{20} \mathrm{O}$ termo inarèhèdu se refere a pessoas, geralmente homens, que passaram por algum tipo de preparo corporal baseado, dentre outras coisas, em jejum prolongado: é o caso de Teribrè. Os que se acostumam a jejuar podem, é claro, passar longos períodos sem comer, mas o jejum também provoca leveza corporal e, por isso, fazia parte do treinamento dos ijàradu, "corredores", homens que se especializavam em corrida de velocidade como técnica para atividades de predação (guerra, caça).
} 
sua filha novamente para você". O pai da menina agradeceu, e disse: "Teribrè, assim eu vou falar para você. Esse rio é nosso, aí está nosso rio. Nossa comida tem as costelas pretas por dentro (itiwolàbyre), nossa comida tem a calda fina (itirudesere). Essas são nossas comidas. Fique com o nosso rio, fique com nossas comidas". Ele entregou o rio Araguaia, que era dos Wèrè, para Teribrè. Entregou também suas comidas, peixes. "Aquele que tem as costelas pretas por dentro", assim eles chamavam o cari da praia (ryriè); "aquele que tem a calda fina", assim eles chamavam o surubim chicote (bargada, kyhyja + , yhyja ठ̂̉) - os nomes são, com efeito, descrições de características de cada espécie. Teribrè aceitou, e the falou: "Está bem. Vocês vão descer novamente para cá trazendo aquilo que precisamos, penas (juraha), óleo de tucum (tari), kowoji, urucum (wòrànỹ), massa de urucum (wònàrỹra). Podem ir para arrumar isso para nós, tragam aquilo que é difícil aqui".

Assim os Wèrè foram embora, subindo o rio. Chegaram até sua aldeia e depois partiram para o interior da Ilha do Bananal, procurando um novo lugar para morarem. Com medo de mais guerras, eles foram embora. Eles foram para o lado do bero biòwa, o outro braço do Araguaia, o rio Javaés. Por isso, hoje, os Javaé estão lá. Os Javaé são Were riokorè, são os netos dos Wèrè, netos daqueles que foram mandados embora por Teribrè.

A expulsão dos Wèrè por Teribrè aparece também, ainda que brevemente, na mitologia Javaé registrada por Rodrigues. Mas, segundo a autora, metade dos Wèrè morreram, ao passo que a outra metade "fugiu para o rio Hèrydèo, no vale do Xingu, onde eles estão até hoje. Alguns creem que os Wèrè sejam os Trumai xinguanos, uma vez que Turumahi é o nome dados os Wèrè pelo povo de Kanõanõ" (RODRIGUES, 2008b, p. 91-2; cf. também TORAL, 1992, p. 18).

Os Inỹ, o pessoal de Teribrè, continuaram morando nas imediações de inỹsèdyna, a passagem pela qual eles tinham saído do fundo do rio, próximo ao local onde hoje está a aldeia Itxala. Então a mãe dele falou para seu filho adotivo, Wanahua: "Eu vou falar para você. Você já cresceu, vocês estão crescidos. Volte para sua terra". Wanahua aceitou, foi embora. Voltou para os seus parentes, foi para a terra dos Kayapó. E os Inỹ continuaram morando lá. Até que, um dia, o horizonte à jusante amanheceu coberto por uma neblina, um dia bastante diferente. Um velho acordou, bem cedo, olhou o tempo e disse para si mesmo: 
"Hèbè! Como pode que o tempo tenha acordado tão bonito! Todo coberto de neblina!" Teribrè escutou aquilo e resolveu mandar o velho e seu pessoal embora: "Eu vou falar para você. Vão, vocês vão para lá, para baixo. Vocês vão para que, quando o dia amanhecer assim, nós nos lembremos de vocês (bàdè biòwana)". Então eles foram morar na parte baixa do rio, no iraru, para que aquilo pudesse ser lembrado. Por isso lá estão os Ixỹbiòwa. Eles são chamados de Ixỹbikòwa ${ }$, Ixỹbiòwa $\widehat{\jmath}$, porque trazem recordação (são bàdè bikòwana ${ }_{+}$, bàdè biòwana ${ }^{\lambda}$ ), por isso o nome deles é Ixỹbiòwa. "Mas eles não são ixỹju!", insiste a narradora da história, "esses que Teribrè mandou embora, eles eram Inỹ"21.

Essa história, assim, conta como os Inỹ ganharam domínio sobre o vale do Araguaia, expulsando os Wèrè, que foram ocupar o outro lado da Ilha, dando origem aos atuais Javaé. Apesar de as narrativas enfatizarem que eles foram "para o outro lado" (kua wèbrò-ò), ou "em direção ao rio Javaés" (bero biòwa-ò), as antigas aldeias javaé, na virada do século XIX para o XX, eram todas no interior da Ilha, à beira de algum rio ou lago, e não à beira do Javaés. As primeiras incursões do SPI aos Javaé no ano de 1930, por exemplo, notaram a existência de sete aldeias, localizando três delas: uma junto ao rio Imõtxi, que corre dentro da Ilha; a aldeia Wari-Wari, que ficava às margens do lago Wari-Wari, a 6 km do rio Javaés; e outra junto ao lago Sohokỹ, também no interior da Ilha (BANDEIRA DE MELLO, 1930; FERNANDES DA COSTA, 1931). Essas aldeias, ao contrário das karajá e javaé atuais, eram circulares, o que é mais um elemento para a identificação feita por Patrícia Rodrigues (2008b) dos Wèrè como um grupo Jê.

A história de Teribrè é também a história da diferenciação entre os três grupos inỹ. Os primeiros escritos tratavam-nos como três "subgrupos karajá". Mas eles são, com efeito, três grupos que, a despeito das inúmeras similaridades, se consideram como distintos. Os Karajá chamam os Javaé de bero biòwa mahãdu, "povo do outro braço do rio", "povo do rio Javaés"; e os Javaé chamam os Karajá

\footnotetext{
${ }^{21} \mathrm{~A}$ narrativa de Mahuèdèru continua narrando os desdobramentos dessa guerra. Teribrè se tornou o primeiro chefe entre os Inỹ. Mas ele não saia da aldeia, com medo de represália. Com efeito, passados alguns anos, os Wèrè começaram a descer o rio procurando por Teribrè (ver NUNES, 2016, p. 577-88). Na primeira oportunidade em que sai da aldeia com uma turma de homens para pescar, ele é emboscado pelos Wèrè, mas consegue escapar. Também Wanahua, seu irmão adotivo, retornaria depois de anos, raptando uma mulher (NUNES, 2016, p. 579-81, M20).
} 
de berohokỹ mahãdu, "povo do Araguaia”. Mas há também designações pejorativas de ambos os lados: Os Karajá se referem, por vezes, aos Javaé como ixỹju mahãdu, "estrangeiros", "não inỹ"; esse termo também é usado pelos Javaé para ser referir aos seus vizinhos do Araguaia, embora haja outro, aparentemente usado com mais frequência, iwa yrè mahãdu, termo que Rodrigues (1993, p. 11) traduziu por "aleijado, sem um pé"22. Assim, se em alguns contextos os Karajá e Javaé se identificam reciprocamente como inỹ, em outros eles se diferenciam, afirmando-se como inỹ e relegando a seus vizinhos o estatuto de ixỹju. Já em relação aos Ixỹbiòwa, essa diferenciação pareceria mais tênue; pois, como vimos acima, se os Javaé são descendentes dos Wèrè, um povo ixỹju, os Ixỹbiòwa são um grupo inỹ que foi mandado por Teribrè para morar no baixo Araguaia. Entretanto, em certos contextos, os Karajá também marcam suas diferenças em relação a eles. No que diz respeito à língua por exemplo, enquanto os Karajá consideram a sua variante e a dos Javaé como formas "adultas", diferenciadas por gênero ${ }^{23}$, afirmam que os Ixỹbiòwa falam "igual criança", se referindo a certas características fonéticas da variante por eles falada.

Como nota Nathalie Pétesch, a divisão entre os três grupos pode ser vista como análoga à divisão tríplice do cosmos e à repartição dos homens em grupos de praça ijoi, apresentando uma estrutura recorrente na sociocosmologia inỹ: um "dualismo assimétrico, com o elemento mediano opondo e se impondo aos dois elementos polares relativamente equivalentes" (PÉTESCH, 1993, p. 370). Karajá e Ixỹbiòwa, que se distinguem respectivamente como ibòò mahãdu ("pessoal de cima") e iraru mahãdu ("pessoal de baixo"), são dois grupos inỹ - seguindo a história de Teribrè - habitantes das margens e das praias do Araguaia, devotados mais à pesca que à agricultura; os Javaé, por seu turno, são um grupo considerado

\footnotetext{
${ }^{22}$ Iwa, "o pé dele"; yrè (língua javaé; em karajá, krè ㅇ, àrè ô), "pedaço, parte"; mahãdu, "pessoal, povo". Registrei alhures (NUNES, 2012, p. 7) uma história que parece explicar essa designação curiosa. Há muito tempo, alguns Karajá estavam se disfarçando de Xavante e roubando a roça dos Javaé. Estes, então, resolveram se esconder e esperar para descobrir quem estava Ihes roubando. Quando os ladrões chegaram de novo, os Javaé avançaram. Um de seus cachorros mordeu o pé de um dos ladrões, que gritou "Akè!" - interjeição de dor, similar ao "ai!", do português, usada pelos homens inỹ - e saiu correndo, mancando. Assim os Javaé descobriram que eram, na verdade, os Karajá disfarçados.

${ }^{23}$ Do ponto de vista dos Karajá, as mulheres javaé falam como homens - a referência aqui é a menor contrastividade das falas masculina e feminina no javaé. Para detalhes das características diferenciais das variantes faladas pelos três grupos, ver Ribeiro (2012).
} 
como ixỹju (por serem descendentes dos Wèrè), que habita a porção mediana do território inỹ - por isso são considerados e se consideram como itya mahãdu, "pessoal do meio" (cf. RODRIGUES, 1993; 2008a) - e que, em contraposição aos Karajá, são associados mais à terra do que à água - suas aldeias antigas ficavam no interior da Ilha, e os Karajá dizem que eles são agricultores mais devotados. Pétesch diagrama essa estrutura de modo muito semelhante à distribuição dos três grupos ao longo do vale do Araguaia e ao plano da aldeia (uma ou mais linhas de casa paralelas ao rio e uma casa ritual masculina localizada na região mediana dessa fileira de casas, mas afastada dela em direção ao mato) - ver Diagrama 1.

Diagrama 1 - O dualismo assimétrico de Nathalie Pétesch

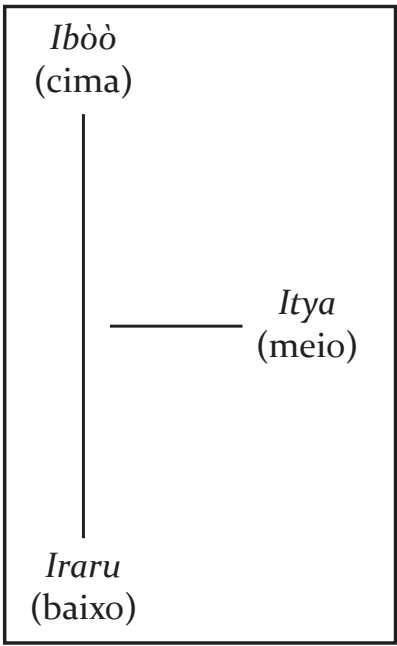

Fonte: Elaboração própria.

Em um nível, com efeito, a divisão entre Karajá, Ixỹbiowa e Javaé é ternária - são três grupos distintos; em outro, os Karajá e Ixỹbiòwa se igualam como inỹ em contraposição aos Javaé, um povo ixỹju. Mas retracemos a sequência dos acontecimentos narrados nas histórias que apresentei até aqui, que culminam com a distinção entre os três grupos inỹ. Veremos, então, que a necessidade de totalização, de imaginar uma estrutura que dê conta, a um só tempo, de virtualmente todas as possibilidades de relação entre os três grupos, some. 
Quando todos saem do fundo do rio liderados por Woubèdu, essa aparente unidade logo se revela como uma dualidade, pois os ixỹju também vieram o acompanhando. A instabilidade do par é enfatizada pela narradora, que nota que a propensão à guerra dos ixỹju inevitavelmente provocaria uma ruptura, cedo ou tarde. Os ixỹju Kymỹkò, então, derrubam/jogam o tòò de Woubèdu, o que inaugura um período de conflitos generalizados, durante o qual o pai de Teribrè é morto pelos Wèrè. A história de Teribrè inicia já introduzindo um outro par, pois é junto com seu irmão Wanahua, um Kayapó criado entre os Inỹ, que ele vai em busca de sua vingança. Eles derrotam os Wèrè, e a instabilidade do par Teribrè/Wanahua é evidenciada por sua mãe que, após seu retorno vitorioso, manda o filho adotivo embora. Teribrè se cansa de ter os Wèrè morando junto de si e os manda embora; eles vão para o outro lado da Ilha, dando origem aos Javaé. Os Inỹ, então, dominam o Araguaia. Ainda assim, um desequilíbrio vem à tona, quando um dia o horizonte amanheceu coberto de neblina. Teribrè manda embora o pessoal do velho que gostou daquele dia atípico, e seu próprio pessoal inicia uma migração rio acima, criando a diferença entre ibòò mahãdu, o "pessoal de cima", os Karajá, e iraru mahãdu, o "pessoal de baixo", os Ixỹbiòwa (ver Diagrama 2). Quando nos situamos em um ponto determinado, nos deparamos sempre com um par. $E$, dentro dele, há sempre uma assimetria, que, no momento seguinte, faz um dos termos em oposição se desdobrar em outro "dualismo assimétrico". A assimetria do dualismo, para retomar o termo de Pétesch, faz com que "as coisas não permaneçam em seu estado inicial e que, de um dualismo instável em qualquer nível que se o apreenda, sempre resulte outro dualismo instável" (LÉVI-STRAUSS, 1993, p. 209). E o que seria a expulsão dos Ixỹbiòwa - quando já não havia mais guerras, e por um motivo aparentemente banal - senão uma expressão dessa instabilidade instalada no interior do par? Resta sempre um coeficiente de diferença. 
Diagrama 2 - Origem da distinção entre os grupos inỹ

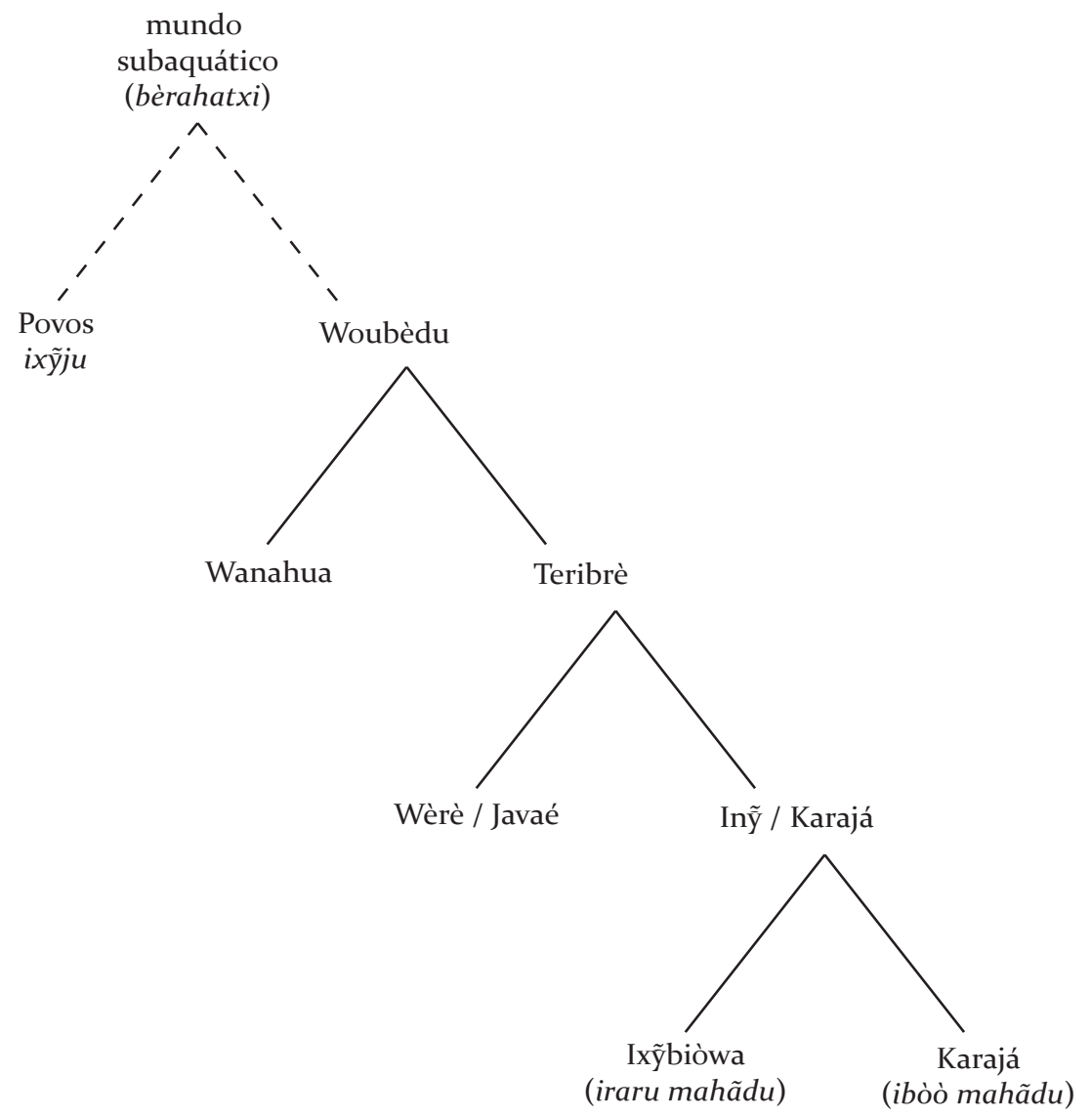

Fonte: Elaboração própria.

\section{VERSÕES DO PESSOAL DE BAIXO E DOS JAVAÉ}

A mesma diferença entre ibòkò $q$, ibòò $\widehat{\sigma}$, "rio acima", e iraru, "rio abaixo", que distingue respectivamente os Karajá dos Ixỹbiòwa, reparte internamente os Karajá em dois grupos territoriais. Os que moram de Buridina, a aldeia mais ao sul (rio acima) do território ocupado hoje pelos Inỹ, até Fontoura, são considerados como ibòò mahãdu ("pessoal de cima") - Santa Isabel faz parte desse conjunto -, ao passo que os moradores das aldeias que ficam na foz do rio Tapirapé (Itxala 
e Hãwalòra) até as duas aldeias em território do estado do Pará (Santo Antônio e Maranbuba), são iraru mahãdu ("pessoal de baixo"). Cada um desses grupos fala uma variante do inỹrybè (RIBEIRO, 2012), que, além de algumas diferenças lexicais, é distinguível do outro pelo sotaque. Há também variações nas práticas rituais e em questões cotidianas.

E essa mesma oposição reaparece dentro de cada aldeia, distinguindo sua população, mais uma vez, entre ibòò ổ mahãdu, "pessoal de cima", e iraru mahãdu, "pessoal de baixo". Esse contraste é particularmente relevante no universo ritual, pois, em praticamente todas as atividades ligadas a ele, os homens se dividem

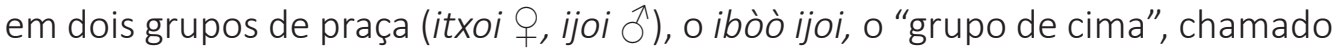
de Hirètu ("pena do rabo de carcará"), e o iraru ijoi, o "grupo de baixo", chamado de Wàkatu ("pena do rabo de mergulhão") ${ }^{24}$. As informações presentes na literatura específica indicam que a estrutura dos grupos ijoi era, em um passado não muito distante, bem mais rica, com vários ijoi repartidos entre "cima", "baixo" e "meio" (ver PÉTESCH, 1993; TORAL, 1992). Uma discussão mais pausada sobre esses grupos de praça nos afastaria demais do objetivo do texto. Cabe apenas notar que, hoje, os homens se dividem apenas entre os grupos de ibòò e iraru e, unicamente durante o ápice do Hetohokỹ, alguns poucos membros de ambos - todos eles homens de idade e/ou xamãs - formam um grupo distinto, os itya mahãdu, "o pessoal do meio", ijoihikỹ, "grande ijoi", ou simplesmente mahãdu. O contraste ibòò/iraru, em suma, replica-se fractalmente, dando continuidade à cascata de dualidades assimétricas diagramada acima.

Ainda sobre os grupos de praça ijoi, as etnografias apresentam algumas informações discrepantes. O grupo Hirètu (ibòò) é alocado por Pétesch entre os ijoi de iraru, ao passo que o grupo Wàkatu, que os Karajá de Santa Isabel afirmaram ser de iraru, foi registrado por Toral como compondo o conjunto dos ijoi de ibòò. Não saberia dizer o motivo exato dessa discrepância. Mas é possível que as várias aldeias tenham versões diferentes sobre a alocação dos grupos de praça como sendo de ibòò ou de iraru. Como me disse certa vez o cacique de Buridina,

\footnotetext{
${ }^{24}$ A pertença a esses grupos "de cima" e "de baixo", distinguidos segundo o mesmo critério de referência utilizado para o rio (montante/jusante), remete ao grupo territorial ao qual se pertence, como bem nota Toral (1992, p. 127). Em Santa Isabel, por exemplo, os iraru mahãdu, "pessoal de baixo", são pessoas cujas famílias são originárias de aldeias que ficam no iraru. Muitos são nascidos ali mesmo, mas os pais vieram de Macaúba ou de Itxala, por exemplo.
} 
Raul Hãwakati, "os antropólogos pensam que, porque é Karajá, todas as aldeias são uma coisa só. Mas não, cada aldeia tem seu costume". Para dar apenas um exemplo: toda vez que os ijasò saem para dançar, a família responsável por eles manda comida para os homens; em Santa Isabel, a comida é para todos os homens que estão na praça e é enviada depois que os Aruanãs acabam de dançar; em Fontoura, a comida também é em grande quantidade, mas primeiro os homens comem e depois saem com os ijasò; já em Macaúba, a comida vai depois, como em Santa Isabel, mas em porções individuais destinadas apenas aos homens que dançaram.

Hoje, em vista do aprofundamento do conhecimento sobre essas diferenças (inclusive entre Karajá e Javaé, embora o caso dos Ixỹbiòwa permaneça ainda como uma lacuna), e considerando mais propriamente as várias diferenciações que os Inỹ fazem entre si, penso que, mais do que nunca, é preciso situar nossas etnografias. Não apenas para reconhecer que variações as há, de modo que não se pode pretender que uma etnografia ancorada em qualquer ponto desse conjunto seja válida, em igual medida, para todos os outros - nenhuma etnografia, afinal, poderia sê-lo. Mas também porque, considerando a maior riqueza e detalhamento do registro etnográfico, estamos agora em melhores condições para explorar as variações que constituem o macro conjunto inỹ como um sistema de transformações, em lugar de submetê-las a uma segmentação dura que as reduza a marcadores de fronteiras entre grupos hierarquicamente relacionados - os Javaé e Ixỹbiòwa como "subgrupos karajá", ao lado dos "Karajá propriamente ditos" - ou igualitariamente seccionados - "três grupos diferentes", entre os quais, então, tudo o que pode haver é comparação. Isso inclusive em relação às variações entre os Karajá "de cima" e "de baixo".

Uma dessas variações diz respeito à história da origem dos Inỹ. Na versão apresentada acima, vimos, Woubèdu saiu do Berahatxi pela passagem chamada inỹsèdyna acompanhado pelos Inỹ do fundo do rio e por todos os grupos ixỹju. Já nas versões dos iraru mahãdu, os ixỹju não saíram junto com Woubèdu, mas sim em outro lugar, um lago chamado Bòra.

Na mesma época e não muito distante, três famílias do povo Wèrè - um povo diferente - também ascenderam do Fundo das Águas, mas em um lugar diferente, o Lago Bòra (Lago do Aristóteles, ver Mapa no 6). Cada uma das famílias dos Wèrè (Wèrètyhy, Wèrèraora, Wèrèlyby) tinha suas pró- 
prias características, embora tenham saído juntas no Bòra. O povo ljewehe também saiu no mesmo lugar, mas logo voltou para baixo, pois não gostou daqui. (trecho de uma versão narrada por Sebastião Waihore, de Macaúba em RODRIGUES, 2008a, p. 83).

O Lago Bòra, como local de ascensão dos Wèrè e outros ixỹju, aparece também em narrativas de pessoas Fontoura registradas por Patrícia Rodrigues (RODRIGUES, 2008a, p. 83-5), embora a versão que gravei nesta aldeia, com Abitxỹna, seja idêntica, em relação a esse ponto, às que escutei em Santa Isabel, nas quais os Inỹ e todos os ixỹju saem juntos de um mesmo local, chamado de inỹsèdyna. Em uma versão contada por Tereza Mahidikè [sic.], moradora de Itxala, saem de inỹsèdyna Woubèdu, Tekumỹka, Kumỹka e Tarawasa, os ancestrais, respectivamente, dos Karajá, Javaé, Ixỹbiòwa e Tapirapé (RODRIGUES, 2008a, p. 85). Segundo a narradora, os Wèrè saíram do fundo do rio, algum tempo depois, no lago Bòra e subiram o rio Araguaia, ao passo que o pessoal de Woubèdu foi para o baixo Javaés (RODRIGUES, 2008a, p. 86) - o mesmo me foi dito pelo professor Paulinho Kòhãluè, morador de Santa Isabel, mas cuja família é de Lago Grande, aldeia abaixo de Macaúba.

Na mitologia Javaé, tal como registrada por Rodrigues (2008b), também não há um único local por onde os vários povos saíram do mundo de baixo.

Há uma memória detalhada dos vários povos que existiam naquele tempo. A maioria era chamada de ixỹju, povos "estrangeiros" que tinham outra língua ou outros costumes. Entre os ixỹju, alguns saíram do Fundo das Águas, mas outros saíram "da terra mesmo" ou já estavam por aqui. Outros eram considerados inỹ, no sentido específico de que falavam línguas parecidas com a dos Javaé atuais, mas eram também povos diferentes entre si, que viviam em lugares diferentes. (RODRIGUES, 2008b, p. 66).

A autora apresenta uma lista de 30 povos diferentes (RODRIGUES, 2008b , p. 68-70), mas nenhum deles corresponde aos Javaé atuais - ao contrário, portanto, das versões, Karajá, em que estes são Woubèdu riokorè, "os netos de Woubèdu". Segundo o material de Rodrigues, os Javaé seriam descendentes de dois povos, os Wèrè e os Tòlòra, que se uniram e casaram entre si. Isso teve lugar em um sítio antigo, Marani Hãwa [sic.], uma aldeia no alto Riozinho, que corta o interior da Ilha. Com a presença desses dois povos ali, mas sobretudo pela presença de Tòlòra, que era iòlò (um tipo de liderança antiga, muito respeitada), Marani Hãwa se 
tornou "o mais importante centro reverenciado pelos estrangeiros" (RODRIGUES, 2008b, p. 87). Vários ixỹju iam até lá para visitar e/ou para assistir e participar dos rituais, trazendo suas comidas e conhecimentos, que foram sendo incorporados às práticas locais. "Tudo que era trazido pelos mais diversos povos como reverência ao iòlò Tòlòra era, por um lado, integrado a esse caldeirão de misturas culturais, que ia aos poucos consolidando novos padrões, seguidos até hoje; por outro, tornava-se uma fonte da qual todos se nutriam, enriquecendo-se com os novos conhecimentos e costumes" (RODRIGUES, 2008b, p. 88). É desse processo de intercâmbios e criações acontecido em Marani Hãwa, segundo Rodrigues, que surgiram os Javaé atuais.

Como herança dos Wèrè teriam ficado, dentre outras coisas, o Hetohokỹ, grande ritual coletivo de iniciação masculina e, importante, sua língua, "embora haja influência daquela que os Kuratanikèhè de Tòlòra falavam e de termos Wou (Tapirapé)" (RODRIGUES, 2008b, p. 88). Segundo os Javaé, os Karajá falam a língua dos Wèrè, que aprenderam em Marani Hãwa; já segundo os Karajá, o pessoal de Woubèdu saiu do Berahatxi já falando inỹrybè, que também era a língua dos Wèrè, que vieram os acompanhando. Mas a referência a termos tapirapé remete a uma outra história de origem dos Javaé. Vimos mais acima que, segundo contam os Karajá "de cima", eles seriam os descendentes do Wèrè derrotados por Teribrè. Mas há uma história contada pelos moradores da antiga aldeia Tytèma, que ficava no rio Tapirapé, a cerca de dois quilômetros de onde ele desemboca no Araguaia (precisamente onde hoje está a aldeia Hãwalòra), que diz que os Javaé são descendentes diretos dos Tapirapé. Conta-se que, no passado, muitas guerras aconteceram entre os Inỹ e os Tapirapé, povo muito belicoso - tanto que o nome deste grupo em inỹrybè, Wou, é também uma palavra para se referir à "guerra". Nesses confrontos, os Inỹ roubavam-Ihes crianças, que criavam como bàdèòbyna, "adotivos" - assim como acontecera com Wanahua, irmão de criação de Teribrè. Com o tempo, esses bàdèòbyna cresceram, mas muitos Inỹ não queriam casar seus filhos com eles por serem ixỹju. Por isso eles quase sempre se casavam entre si - havia exceções, é claro. Então os "chefes" (wèdu) dos Tapirapé adotivos, seus pais, seus avós, conversaram com o pessoal para resolver a questão. Eles mandaram os bèdèòbyna, que já eram muitos entre os Inỹ, para morar no rio Javaés, de modo que, quando os Karajá fossem até eles, pudessem matar pássaros para tirar pena, pegar tartaruga, matar porco queixada etc. E assim eles partiram e lá 
se estabeleceram, dando origem aos Javaé atuais.

Uma versão dessa narrativa, contada pelo finado Erehani, foi publicada por Pimentel da Silva e Rocha (2006, p. 139-45). Quem primeiro me contou essa história, porém, foi Gedeon Ijàraru, morador de Buridina, neto do mesmo Ereheni. Segundo ele, "os Javaé são Tapirapé puros". Como haviam sido raptadas ainda crianças, os bàdèòbyna "tinham esquecido praticamente tudo da cultura tapirapé, lembravam só uma coisa ou outra". Essas poucas lembranças seriam responsáveis por algumas peculiaridades dos Javaé em relação aos Karajá. Dentre elas, a presença de termos tapirapé na língua falada por eles e a extrema semelhança entre seus Lateni, tipo de entidade mascarada que sempre acompanha os ijasò ritual que os Tapirapé incorporaram dos Karajá. Sobre a língua, há alguns poucos empréstimos tapirapé no inỹrybè, sobretudo na variante falada pelos Karajá "de baixo" (iraru mahãdu), que, historicamente, tiveram uma convivência muito mais próxima com esse grupo Tupi. Esses termos estão presentes também na língua javaé, que conta ainda com um quadro de empréstimos tapirapé de ocorrência exclusiva, nomes pessoais dentre eles (cf. RIBEIRO, 2012).

Essa versão da origem Tapirapé dos Javaé, note-se, é uma variação (condensada) da história da guerra de Teribrè contra os Wèrè. Nela, vimos, a instabilidade entre inỹ e ixỹju emerge no seio do grupo que saiu do fundo do rio junto com Woubèdu e culmina em um estado de guerra generalizada. $O$ fato de que Teribrè tem um irmão de criação ixỹju remete já à guerra: Wanahua, provavelmente, foi raptado aos Kayapó. O rapto análogo de crianças tapirapé, porém, condensa a história de Teribrè até o momento em que os Wèrè passam a morar junto a ele, introduzindo o mesmo contraste inỹ/ixỹju adotado, mas não no par de germanos, como Teribrè e Wanahua, e sim como afins potenciais, como Teribrè e a menina Wèrè. $E$, aqui, é também a negação do casamento 25 que precipita a "expulsão" daqueles que viriam a se tornar os Javaé, em condições de "servidão" análogas à dos Wèrè, wetxu de Teribrè: os Tapirapé adotados são mandados embora de modo a facilitar o acesso dos Inỹ a certos itens e alimentos (ver Diagrama 3).

\footnotetext{
${ }^{25}$ Que, note-se, aparece invertida: Teribrè se recusa a casar com uma mulher wèrè que lhe foi oferecida, ao passo que, na outra história, são os Inỹ que recusam a possibilidade dos Tapirapé se casarem entre eles, i.e., recusam a entregar mulheres (ou homens) solicitados como cônjuges.
} 
Diagrama 3 - Origem da distinção entre os grupos inỹ (2)

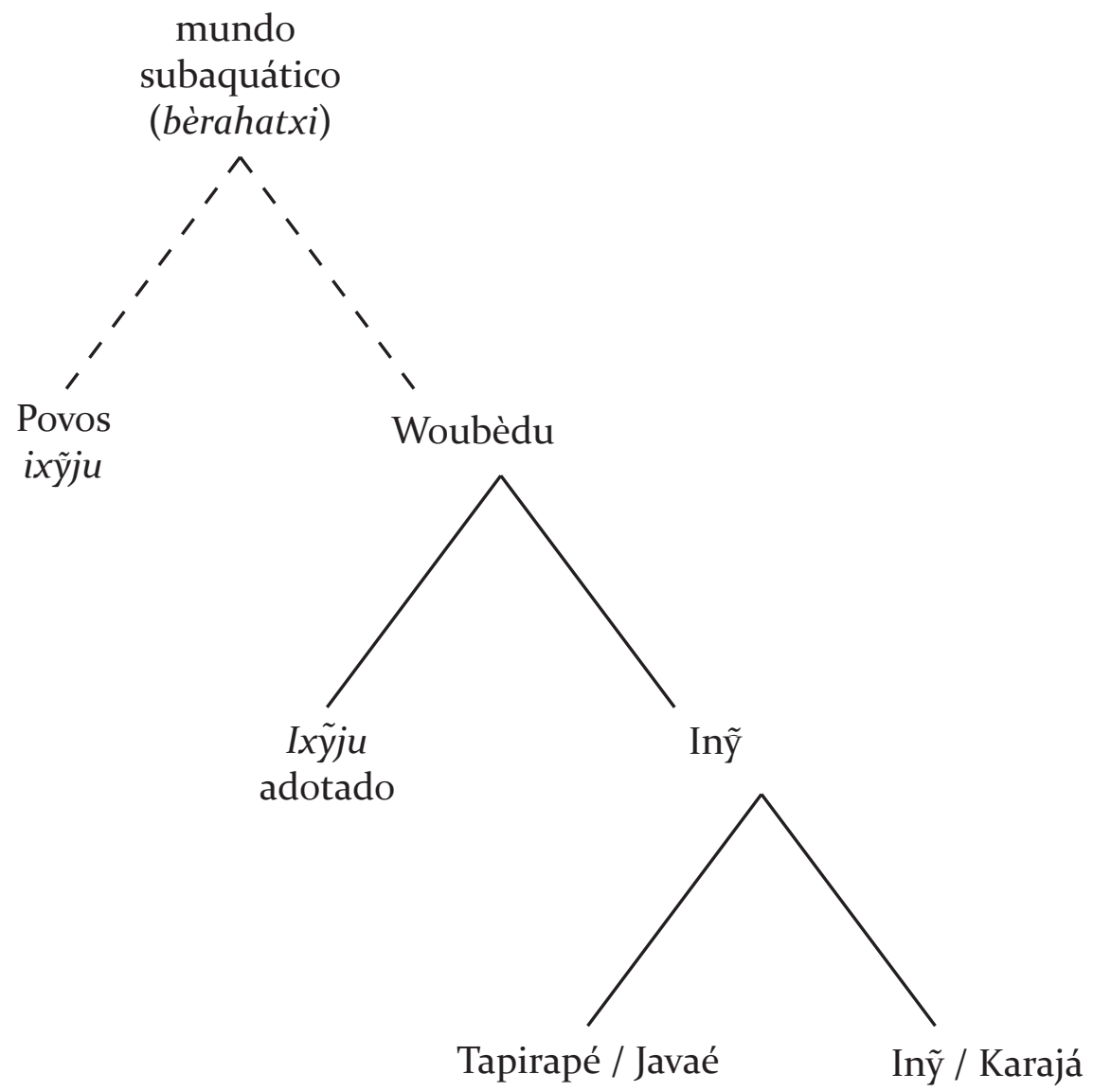

Fonte: Elaboração própria

\section{VARIAÇÕES MÍTICAS, VARIAÇÕES ANTROPOLÓGICAS}

As diferentes versões karajá das histórias de origem e diferenciação dos grupos inỹ que vimos aqui operam dois princípios dicotômicos básicos: inỹ/ixỹju e ibòò/iraru (montante/jusante). Seguindo o Diagrama 2, o contraste entre os Inỹ e outros índios que emerge no interior de cada par (da emergência dos ixỹju junto com Woubèdu à ida dos Wèrè para leste dando origem aos Javaé) se desdobra no contraste "de cima"/"de baixo": primeiro quando os Ixỹbiòwa são mandados 
para o baixo Araguaia; depois com a divisão interna dos Karajá entre "pessoal de cima" e " pessoal de baixo"; e, por último, com a divisão interna à cada aldeia entre grupos de praça de ibòò e de iraru.

Esse desdobramento de um contraste em outro, vale notar, é uma passagem do eixo leste-oeste para o eixo sul-norte. Pois, para os Inỹ, moradores da beira do rio, os ixỹju são moradores do bàdèrahyky $q$, bàdèrahy $\widehat{\jmath}$, "mato", moradia também de animais e de espíritos perigosos (os aõni) e antítese da aldeia, espaço humanizado por excelência. Referente a esse contraste, há dois termos que indicam direções opostas no eixo leste-oeste: bekyra + , beyra $\partial^{\lambda}$, "em direção ao rio", e ibràra, "em direção ao mato". Mas se o rio tem duas margens, a direção em que o "mato" está, se a leste ou a oeste, depende de em qual margem do rio nos encontramos. Ainda que alinhado ao eixo do sol, o contraste beyra/ibràra não é orientado, aparecendo ora como leste-oeste ora como oeste-leste ${ }^{26}$. Voltando às nossas histórias, Wanahua, o Kayapó, está para seu irmão adotivo Teribrè assim como ibràra (oeste) está para beyra (leste) - idem para o caso dos Tapirapé adotados, segundo a versão dos Karajá "de baixo"; e os Wèrè estão para Teribrè que os expulsou assim como ibràra (leste) está para beyra (oeste) - idem para a relação entre os primeiros humanos e a humanidade verdadeira que saiu do fundo do rio.

As histórias aqui tratadas, operando contrastes ancorados em um eixo ou em outro, fazem aparecer recursivamente uma diferença onde antes havia um par (ou uma multiplicidade) sob unidade aparente. O desdobramento do contraste ibràra/beyra no contraste ibòò/iraru, note-se, assinala a continuidade desse processo recursivo de diferenciação do contexto inỹ-ixỹju para o contexto interno à humanidade inỹ - as diferenciações fractais dos Karajá em grupos "de cima" e "de baixo". Humanidade essa que pode desde englobar o macro conjunto Karajá, Javaé e Ixỹbiòwa até se restringir a um grupo territorial específico, a depender do contexto.

O caráter não orientado do contraste ibràra-beyra é particularmente interessante aqui. Pois, ainda que estejamos lidando com histórias, as sucessivas diferenciações só são orientadas no interior da narrativa. Essas histórias nos colocam diante de modos de operacionalização da diferença genérica Eu-Outro, semelhante-diferente, em termos de contrastes presentes também nas rela-

${ }^{26}$ Sobre essa cartografia cósmica, ver Nunes (2016, p. 331-4). 
ções inỹ atuais; nesse último caso, entretanto, eles não são orientados. Karajá e Javaé, como vimos, se consideram como grupos distintos. Isso, é claro, em certos contextos. Em outros, reconhecem-se mutuamente como inỹ, em contraposição a Outros. Esse caráter "não orientado" da relação entre os dois grupos, por assim dizer, estava marcado já na história da saída do fundo do rio, que vimos mais acima. Diante da multiplicidade de povos que emergem, Woubèdu descreve-os um por um para Ura-Ura, o sobrevivente da humanidade primeva que havia acabado de chegar ao Araguaia com os seus. Nesse momento, Dòrewaru, a narradora, pontua que os Wèrè e os Tapirapé eram ityhy, "verdadeiros", "nobres", "belos", e emergiram do fundo do rio já ricamente ornamentados com os enfeites que hoje são inỹ - cocares de penas, braceletes e tornozeleiras de algodão tingido com urucum, brinco de dente de capivara etc. Seu caráter humano, inỹ, é marcado pela narrativa, ao contrário do que acontece com Woubèdu que, apesar de ser descrito como inỹdèri (expressão que poderíamos traduzir aproximadamente por "verdadeiramente humano", "verdadeiramente pessoa"), possuía uma ornamentação corporal grotesca, em clara discrepância com o caráter ityhy ("legítimo", outra tradução que poderíamos oferecer) dos Wèrè e Tapirapé: em lugar de urucum, ele esfregava um barro vermelho no corpo, seu tari (óleo de coco de tucum) era a banha do peixe filhote (bèdò), e seus enfeites se resumiam a cordas de embira embaraçadas atadas ao punho e à testa.

E mesmo no que diz respeito ao contraste ibòò-iraru. Aparentemente orientado (montante/jusante), há pelo menos um contexto em que ele pode aparecer invertido. O Hetohokỹ, o grande ritual de iniciação masculina, requer, em sua fase principal, a participação da coletividade masculina de uma aldeia visitante. Os anfitriões assumem, no pátio ritual (ijoina §̂), o polo "de cima" (ibòò đ̂), ao passo que os visitantes ficam à iraru, na parte "de baixo" do pátio. Os visitantes do ritual de Santa Isabel são, tradicionalmente, os homens de Fontoura, aldeia cerca de $30 \mathrm{~km}$ rio abaixo, de modo que a posição dos dois grupos no pátio ritual replica a posição relativa das duas aldeias. Em Fontoura, entretanto, os homens que tradicionalmente visitam seu Hetohokỹ, formando o grupo opositor, são os de Santa Isabel. Ali, portanto, as posições se invertem: os homens de Fontoura assumem a parte "de cima" do pátio, mesmo que sua aldeia esteja rio abaixo em relação à aldeia visitante.

As histórias karajá sobre a origem e diferenciação da humanidade inỹ, assim, 
nos fornecem um modelo para pensar as múltiplas relações - de assemelhamento e diferenciação - entre os três grupos inỹ, e mais além. Como vimos, o contraste ibòò/iraru é interno a cada aldeia; assim como o contraste beyra/ibràra, "em direção ao rio" /"em direção ao mato", que opõe o espaço residencial ao pátio ritual e, consequentemente, mulheres e homens, de modo que as diferenciações de que tratamos aqui podem ser colocadas a serviço de uma quantidade de outras questões. O modelo que essas histórias colocam, portanto, não se restringe a elas; pois um mesmo modo de relação perpassa diferentes níveis, desde os três grupos inỹ ao interior da aldeia, da pessoa.

O exercício que fiz nesse artigo é, certamente, bastante limitado. Restaria, ainda, por exemplo, analisar como as versões javaé da origem da humanidade poderiam, ou não, ser equacionadas ao esquema relacional que apresentei aqui. No entanto meu objetivo foi menos o de uma análise sistemática nesse sentido (e mais, se for o caso, o do registro das histórias karajá de Santa Isabel e de algumas de suas variações) que o de chamar atenção para dois aspectos, segundo entendo, pouco explorados pela literatura específica. De um lado, e como já disse claramente, extrair das narrativas apresentadas um modelo mais sofisticado para pensar a relação entre Karajá, Javaé e Ixỹbiòwa como alternativa para seu escalonamento hierárquico (os "subgrupos karajá") ou seccionamento igualitário ("três grupos distintos"). Semelhança ou diferença, aqui, são efeitos de relação, e não estatutos dados à priori. De outro, e consequentemente, apontar para a necessidade de que as diferenciações entre os três grupos - assim como aquelas internas a cada um deles - sejam evidenciadas, e não eclipsadas em nossas etnografias. Pois é só a partir delas que podemos explorar o macro conjunto inỹ como um sistema de transformações. Espero que esse artigo, de alguma maneira, contribua para demonstrar a produtividade dessa empreitada.

\section{REFERÊNCIAS}

BANDEIRA DE MELLO, Darcy Siciliano. Carta de Darcy Siciliano Bandeira de Mello ao encarregado da Inspetoria do estado de Goyaz do SPI, Alencarliense Fernandes da Costa, 16/01/1930. Arquivos do Museu do Índio, Rio de Janeiro, 1930.

DAVIS, Irvine. Some Macro-Jê relationships. International Journal of American Linguistics, v. 1, n. 34, p. 42-47, jan. 1968. 
DONAHUE, George. A contribution to the ethnography of the Karajá indians of central Brazil. 1982. Tese (Doutorado em Antropologia)- Universidade da Virgínia, Virgínia, EUA, 1982.

ERENHEICH, Paul. Contribuições para a etnologia do Brasil. Revista do Museu Paulista, v. 2, p. 7-135, 1948.

FERNANDES DA COSTA, Alencarliense. Relatório anual da inspetoria de Goyaz do SPI, ano de 1930. Arquivos do Museu do Índio, Rio de Janeiro, 1931.

LÉVI-STRAUSS, Claude. O cru e o cozido. Mitológicas 1. São Paulo: Cosac \& Naify, 2004. . História de Lince. São Paulo: Companhia das Letras, 1993.

LIPKIND, William. Carajá Cosmography. The Journal of the American Floklore, v. 53, n. 210, p. 248-51, 1940.

NUNES, Eduardo S. Transformações karajá: os "antigos" e o "pessoal de hoje" no mundo dos brancos. 2016. Tese (Doutorado em Antropologia Social) - Universidade de Brasília (UnB), Brasília, 2016.

. No asfalto não se pesca. Parentesco, mistura e transformação entre os Karajá de Buridina (Aruanã - GO). 2012. Dissertação (Mestrado em Antropologia Social) Universidade de Brasília (UnB). Brasília, 2012.

PÉTESCH, Nathalie. A trilogia Karajá: sua posição intermediária no continuum jê-tupi. In: VIVEIROS DE CASTRO, Eduardo B.; CARNEIRO DA CUNHA, Manuela M. (Org.). Amazônia: etnologia e história indígena. São Paulo: NHII-USP/Fapesp, 1993. p. 365-81.

. La pirogue de sable. Modes de representations e d'organization d'une societe du fleuve: les Karajá de l'Araguaia (Brésil Central). 1992. Tese (Doutorado) - Université de Paris x (Natèrre), Paris, 1992.

PIMENTEL DA SILVA, Maria S.; ROCHA, Leandro M. Linguagem especializada. Mitologia Karajá. Goiânia: Editora UCG, 2006.

RIBEIRO, Eduardo Rivail. A grammar of Karajá. 2012. Tese (Doutorado em Linguística) Universidade de Chicago, Chicago, Illinois, EUA, 2012.

RODRIGUES, Patrícia de M. Terra Indígena Utaria Wyhyna (Karajá) / Iròdu Iràna (Javaé). Relatório de Identificação e Delimitação. Brasília: FUNAI, 2008a.

A caminhada de Tanỹxiwè: uma teoria Javaé da história. 2008b. Tese (Doutorado em Antropologia)- Universidade de Chicago, Chicago, Illinois, EUA, 2008b.

. O povo do meio: tempo, cosmo e gênero entre os Javaé da Ilha do Bananal. 1993.

Dissertação (Mestrado em Antropologia) - Universidade de Brasília (UnB), Brasília, 1993. 
TAVEIRA, Edna L. M. Etnografia da cesta Karajá. Goiânia: Editora UFG, 2012.

TORAL, André. Cosmologia e sociedade Karajá. 1992. Dissertação (Mestrado em Antropologia Social) - Museu Nacional, Universidade Federal do Rio de Janeiro (UFRJ), Rio de Janeiro, 1992.

\section{Sobre o autor:}

Eduardo Soares Nunes: Doutor em Antropologia Social pela Universidade de Brasília e pesquisador associado ao Laboratório de Antropologias da T/ terra (DAN-UnB).Professor do Bacharelado em Antropologia do Programa de Antropologia e Arqueologia da Universidade Federal do Oeste do Pará (PAA-Ufopa).

E-mail: eduardo.s.nunes@hotmail.com

Recebido em 30 de setembro de 2017

Aprovado para publicação em 17 de novembro de 2017 